\title{
Article \\ Effects of Emerging-Economy Firms' Knowledge Acquisition from an Advanced International Joint Venture Partner on Their Financial Performance Based on the Open Innovation Perspective
}

\author{
Choo Yeon Kim, Eun-Hwa Seo, Canisha Booranabanyat and Kwangsoo Kim * \\ College of Business Administration, Konkuk University, Seoul 05029, Korea; chookim@konkuk.ac.kr (C.Y.K.); \\ chew70@daum.net (E.-H.S.); kaewnam@konkuk.ac.kr (C.B.) \\ * Correspondence: kkim@konkuk.ac.kr
}

Citation: Kim, C.Y.; Seo, E.-H.;

Booranabanyat, C.; Kim, K. Effects of Emerging-Economy Firms

Knowledge Acquisition from an Advanced International Joint Venture Partner on Their Financial

Performance Based on the Open

Innovation Perspective. J. Open Innov.

Technol. Mark. Complex. 2021, 7, 67.

https://doi.org/10.3390/joitmc7010067

Received: 18 January 2021

Accepted: 18 February 2021

Published: 20 February 2021

Publisher's Note: MDPI stays neutral with regard to jurisdictional claims in published maps and institutional affiliations.

Copyright: (c) 2021 by the authors. Licensee MDPI, Basel, Switzerland. This article is an open access article distributed under the terms and conditions of the Creative Commons Attribution (CC BY) license (https:// creativecommons.org/licenses/by/ $4.0 /)$
Abstract: Although emerging-economy firms (E-E firms) must have a keen interest in improving their performance by utilizing knowledge transferred from their advanced international joint venture (IJV) partner, there has been little research on the performance implications of E-E firms' knowledge transferred from their advanced IJV partner. So, drawing on open innovation and organizational learning perspectives, we examine whether, how, and when E-E firms' knowledge acquisition from their IJV partner has a positive impact on their financial performance. Based on data collected from 127 Thai manufacturing firms with a local IJV partnered with an advanced overseas firm, our results reveal that E-E firms' knowledge acquisition from their IJV partner has an overall positive influence on their financial performance in terms of growth and profitability. Our results further show that innovation performance mediates the relationship between E-E firms' knowledge acquisition and their financial performance based on a moderated mediation analysis including innovation performance as a mediator and absorptive capacity as a moderator. It is also found that the positive mediation effect of innovation performance is more pronounced in the presence of higher absorptive capacity than otherwise. That is, our results show that even among E-E firms which have acquired much knowledge from their IJV partner, those with higher absorptive capacity achieve better innovation performance than those with lower absorptive capacity, and improved innovation performance subsequently contributes to producing superior financial performance. The key conclusions, implications, and limitations of our study are presented based on these findings.

Keywords: knowledge acquisition; innovation performance; absorptive capacity; financial performance; emerging-economy firms; IJV partner

\section{Introduction}

In today's rapidly changing knowledge-intensive environments, firms can no longer rely solely on internal knowledge, so they search for external knowledge for their innovation in cooperation with various external sources to gain sustainable competitive advantage [1-4]. In this regard, external learning has become a key motive for firms to enter into alliances with other firms as a means of open innovations [5-13], and such a shift in learning strategy in private sectors has also influenced governments to create a more favorable climate for open innovation [14-17]. It is true that firms can acquire knowledge and learn from their partners through various forms of alliances, but they generally prefer joint ventures over other forms of alliances when they intend to acquire hard-to-transfer knowledge from their alliance partners $[18,19]$.

In particular, emerging-economy firms (E-E firms) tend to possess relatively limited knowledge, including technology, so they are likely to have a greater need to enhance their knowledge base with more advanced knowledge transferred from firms in developed economies [20]. For this purpose, E-E firms may rely on an international joint venture (IJV) as an important vehicle of open innovation to acquire such knowledge, especially 
tacit knowledge, from their advanced foreign partner in order to gain competitive advantage [21,22], even though an IJV may pose various issues and problems, such as potential partner opportunism, cultural and managerial conflicts, and instability due to changes in bargaining power [23].

For these reasons, research on E-E firms' knowledge acquisition for innovation from their advanced IJV partner has been on the rise [24-31]. For example, Lin [26] examined the effect of US partners' management control, influenced by Chinese partners' learning intent and IJV performance, on Chinese partners' managerial knowledge acquisition through IJVs. Pak and Park [27] investigated the determinants of knowledge transfer in terms of relationand knowledge-specific variables from advanced foreign partners to local partners through IJVs. Based on a case analysis, Ado, Su, and Wanjiru [24] examined how African local partners acquire knowledge from Chinese partners through IJVs. As such, the existing literature on E-E firms' knowledge acquired from their IJV partner has focused on studying the antecedents or determinants of E-E firms' knowledge acquisition.

However, to our surprise, researchers have paid little attention to investigating the actual performance implications of E-E firms' knowledge acquisition from their advanced IJV partner. This may be due to an implicit assumption in the literature that E-E firms' knowledge transferred from their IJV partner will unquestionably improve their financial performance through open innovation. However, this may not be the case, since all E-E firms are not likely to have the same capabilities to convert knowledge transferred from their IJV partner into useful new knowledge or innovation fit for their context [32-36], which subsequently will be exploited for commercial purpose. So, managers of E-E firms will be keenly interested in understanding the following three issues related to the performance implications of E-E firms' knowledge acquisition for innovation from their IJV partner: (1) Whether knowledge acquired by E-E firms from their IJV partner will, in fact, influence their bottom-line financial performance positively; (2) if so, how (through what mechanism) it will influence E-E firms' financial performance positively; and (3) when (under what condition) it will influence E-E firms' financial performance more positively.

In regard to these issues, three specific research questions are proposed in our study as follows: (1) Does knowledge acquisition by E-E firms from their IJV partner have a positive effect on their financial performance? (2) Does innovation performance mediate the positive effect of knowledge acquisition by E-E firms on their financial performance?, and (3) Does absorptive capacity moderate the positive effect of knowledge acquisition by E-E firms on their financial performance through innovation performance?

Hence, to address these questions, we first investigate whether E-E firms' knowledge acquisition from their advanced IJV partner has a positive relationship with their financial performance in terms of growth and profitability. We further examine the role of secondary innovation as a mediator between E-E firms' knowledge acquisition from their partner and their financial performance in a mediation model. Secondary innovation as a form of open innovation strategy refers to firms' dominant innovation process in latecomer economies that "begins with technology acquisition from developed countries and develops further along the acquired technologies' existing trajectories within established technological paradigm" [37,38], and it is known to be an effective conduit through which E-E firms overcome their inherent technological disadvantages and difficulties in catching up [39]. By extending the proposed mediation model above, we then examine how the effect of E-E firms' knowledge acquisition from their partner on their financial performance through (secondary) innovation performance varies depending on their absorptive capacity in a unified moderated mediation model. Success in innovation requires more than mere access to novel ideas [40], and it depends on firms' ability to assimilate acquired knowledge into their context and apply new knowledge to commercial ends [41,42]. This ability, known as absorptive capacity, determines the extent to which externally acquired knowledge is converted into new products from which firms can reap financial benefits [42].

Based on open innovation and organizational learning perspectives, we argue in this study that E-E firms' knowledge acquisition from an advanced IJV partner will have a 
positive effect on their financial performance (direct effect), that innovation performance will mediate a positive effect of E-E firms' knowledge acquisition on their financial performance (mediation effect), and that a positive effect of E-E firms' knowledge acquisition on their financial performance through innovation performance will be stronger with higher absorptive capacity than with lower absorptive capacity (moderated mediation effect).

For empirical investigation, we collected a total of 127 effective data using questionnaire surveys of Thai manufacturing firms in nine industry sectors that have established an IJV in Thailand with an advanced overseas partner from the US, Japan, or Korea. Thailand, one of the fast-growing countries in Asia, is a typical example of a country with an emerging economy. The key results of our study include: (1) E-E firms' knowledge acquisition from an advanced IJV partner has a positive effect on their financial performance in terms of sales growth and return on sales; (2) E-E firms' innovation performance partially mediates a positive effect of E-E firms' knowledge acquisition on their financial performance; and (3) a positive effect of E-E firms' knowledge acquisition on their financial performance through innovation performance is stronger when E-E firms have higher absorptive capacity.

The remaining part of our paper is structured as follows. In the next section, we review and discuss the theoretical background of our study. In the subsequent section, we explain our research model and propose our hypotheses on the relationships among E-E firms' knowledge acquisition from their IJV partner, innovation performance, absorptive capacity, and financial performance, followed by a section describing the methodology of our study. In the following section, we test the hypotheses of our study and present the results of our analyses, followed by the last section providing the conclusions, implications, and limitations of our study with future research.

\section{Theoretical Background}

\subsection{E-E Firms' Knowledge Acquisition for Open Innovation from an Advanced IJV Partner}

To gain competitive advantage, firms need to innovate based on knowledge or capabilities in key management activities, including product development and production [28,43]. However, E-E firms' ability to innovate internally tends to be relatively weak due to their limited internal knowledge base [44]. So, it seems to be more realistic and important for E-E firms to pursue open innovation by acquiring knowledge externally through partnerships with advanced foreign firms $[21,24,26,27]$.

For this reason, in efforts to pursue open innovation, E-E firms are likely to be active in promoting strategic alliances with advanced overseas firms. At the center of the motivation of E-E firms for alliance partnerships lies their intention, although possibly varying in degree, to acquire knowledge through advanced foreign partnerships [24,26,45]. However, as E-E firms pursue different types of knowledge, they may prefer varying types of alliance partnerships. If the knowledge pursued by E-E firms is more explicit, it will be relatively easier to transfer it through such simple means as documentation, but if it is more tacit, it will be more difficult to transfer it due to its embedded relationships with the skills or capabilities of individuals and organizations [46,47]. In this regard, in cases when the knowledge that E-E firms intend to acquire from partnerships with advanced overseas firms has a higher level of tacitness, E-E firms are likely to choose an IJV as the most desirable among various types of strategic alliances [18]. Usually, tacit knowledge acquired from foreign partners through IJVs is a vital source for E-E firms to gain their sustainable competitive advantage [26].

In the context of IJV partnerships, E-E firms do not usually acquire the necessary knowledge or capabilities directly from advanced overseas partners. Instead, they do so through an IJV $[6,48]$. More specifically, advanced foreign partners first inject tangible and intangible resources, including promised knowledge and capabilities, into an IJV, and then E-E firms acquire necessary knowledge and capabilities through their links with the IJV, such as management involvement. Knowledge acquisition by E-E firms in this process may not occur automatically, but rather it tends to require concerted efforts by E-E firms. 
Existing studies have examined the factors affecting E-E firms' knowledge acquisition for innovation from advanced foreign partners through IJVs. According to the literature, such knowledge acquisition is influenced by E-E firms' learning intent or motivation $[23,30,49]$, absorptive capacity $[19,25]$, management involvement $[45,50]$, social interactions and trust between partners [9,18], common processes and values [51,52], knowledge characteristics [53], equity ownership [54], and learning mechanisms [48].

\subsection{Financial Performance}

Financial performance can be referred to as the final outcome of all the business activities of a firm, and it can also be said to be a bottom line that a firm must pursue in order to survive as a going concern [55]. For this reason, the aim of E-E firms to acquire diverse knowledge from advanced overseas partners through IJVs may be initially to seek innovations in terms of product development, production, marketing/sales, and management, but will be ultimately to secure competitive advantage and pursue financial performance through such innovations. Furthermore, the basic premise for the survival of firms as sustainable entities will be profitable growth. In this respect, our study focuses on financial performance in terms of growth, which indicates how fast a firm grows, and profitability, which implies how profitable a firm is. Accordingly, our study aims to analyze how E-E firms' knowledge acquisition from an advanced IJV partner affects their financial performance in terms of growth and profitability [56].

\subsection{Innovation Performance and Mediation Role}

As suggested by Teece [57], innovation can be viewed as an interactive process of generating something new, such as new technologies, products, and knowledge based on existing capabilities and knowledge inside and outside an organization. Such innovation usually becomes a critical element for firms to create competitive advantage to sustain profitable growth [58]. Based on this, innovation performance can further be defined as the outcomes of innovation, appearing in the form of applying for patents, developing new technologies, developing new products, entering new markets, and gaining competitive advantage through innovation activities [59]. That is, innovation performance can include such outcomes of innovation as patents, new technologies, new product developments, new product introductions, and sales increase due to new product launches [60]. In addition, the literature shows that innovation performance can be measured differently in accordance with various definitions above. For example, innovation performance can be measured either by patents, new technology developments, new product developments, and new product launches [61], or by the contribution of new product launches to a firm's overall sales and profits [2].

The open innovation perspective argues that it is important for firms to improve innovation or innovation performance through interactions with external sources for sustainable competitive advantage [1]. This perspective suggests that knowledge acquired from external sources will facilitate firms' innovation or innovation performance, through which firms are likely to enhance their financial performance. As such, the open innovation perspective seems to propose innovation or innovation performance as a mechanism linking E-E firms' knowledge acquisition from their advanced IJV partner to their financial performance in the context of the IJV partnership. Thus, it is expected that innovation performance tends to play a role as a mediator of the relationship between E-E firms' knowledge acquisition from an IJV partner and their financial performance.

\subsection{Absorptive Capacity and Moderated Mediation Role}

Absorptive capacity can be defined as firms' ability to recognize the value of external knowledge, assimilate it, and exploit it for commercial purposes [41]. Furthermore, Zahra and George [42] argued that absorptive capacity consists of the process of identifying and securing valuable external knowledge, analyzing and interpreting external knowledge in relation to internal knowledge, combining external knowledge with internal knowledge, 
and utilizing and commercializing new knowledge. This implies that a critical process of absorptive capacity is to assimilate and combine external knowledge with internal knowledge to create and utilize new knowledge for firms' sustainable competitive advantage once external knowledge is recognized and obtained. In this regard, it becomes important for firms to possess internal knowledge in the first place to be combined with external knowledge to generate new knowledge suitable for their context, since such internal knowledge can facilitate the whole process of absorptive capacity mentioned above. For this reason, existing research argues that firms' absorptive capacity depends on their internal R\&D capability which relates to their internally knowledge-generating ability [41]. Based on this rationale, $R \& D$ intensity has often been used in previous studies as a proxy to measure or capture firms' absorptive capacity [41].

According to the literature, success in innovation can come from knowledge acquired from external sources like alliance partners [1], but it may not be assured by just simple access to external knowledge [40]. Rather, success in innovation also depends on firms' ability to assimilate externally acquired knowledge into their context and combine it with their internal knowledge to create and apply new knowledge to commercial ends $[41,42,62,63]$. This implies that absorptive capacity tends to influence the extent to which external knowledge obtained is converted into innovation or innovation performance, such as new products or new product sales, through which firms can improve their bottom-line financial performance [42]. Therefore, we expect that absorptive capacity is likely to play a role as a moderator of the effect of E-E firms' knowledge acquisition from an advanced IJV partner on their financial performance through innovation performance.

\section{Model and Hypotheses}

To address our research questions, we developed the research model of our study as presented in Figure 1. In the first subsection, we theorize the effect of E-E firms' knowledge acquisition from an advanced IJV partner on their financial performance with respect to our first research question. In the second subsection, we theorize the mediation effect of innovation performance on the relationship between E-E firms' knowledge acquisition from an IJV partner and their financial performance in relation to our second research question. In the last subsection, we theorize the moderation effect of absorptive capacity on the effect of E-E firms' knowledge acquisition on their financial performance through innovation performance to deal with our last research question.

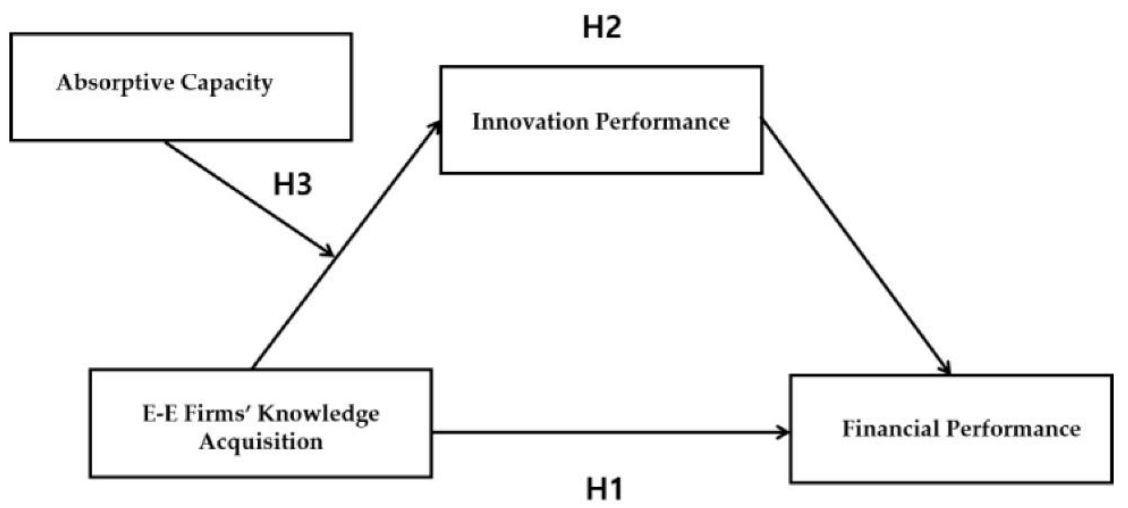

Figure 1. Research model.

\subsection{E-E Firms' Knowledge Acquisition from an Advanced IJV Partner and Their Financial Performance}

According to the organizational learning perspective, knowledge acquisition from external sources is important for firms to gain sustainable competitive advantage [1]. External knowledge can provide new insights into business, technology, and management [60], thereby greatly contributing to firms' success [61]. Similarly, in the context of IJV partnerships, E-E firms can acquire new knowledge for innovation from an advanced IJV partner 
for their sustainable competitive advantage [6,48]. They can acquire knowledge related to product development and production, marketing and sales, and general management from a foreign partner. Such knowledge tends to enable E-E firms to develop their capabilities for superior innovation, quality, efficiency, and customer response [64], which are likely to allow E-E firms to differentiate or lower costs. Eventually, this will generate higher financial performance for E-E firms [64-66].

Specifically, E-E firms' capabilities for superior innovation, quality, and customer response, which have been developed based on newly acquired knowledge about product development, production, marketing, and others from an IJV partner [67-69], are likely to enable E-E firms to pursue differentiation in terms of their products and markets [64]. Through such differentiation, E-E firms will be able to expand their customer base by meeting varied customer needs better and improve profit margins through price premiums by raising value to customers, which eventually are expected to contribute to improving their financial performance with respect to sales and profits $[65,66]$. Likewise, E-E firms capabilities for superior efficiency, innovation, and quality, which has been developed based on knowledge about manufacturing process, quality control, and other information acquired from foreign partners, tend to enable E-E firms to pursue low costs or cost reduction [64]. Such low cost or cost reduction is likely to allow E-E firms to expand their customer base by lowering prices of products to reflect cost savings or increase profit margins of their products, which subsequently will result in improved sales and profits [65-67].

In summary, knowledge acquisition by E-E firms from an IJV partner is expected to have a positive impact on their financial performance in terms of growth and profitability. Based on the discussions above, we proposed the following hypothesis.

Hypothesis 1. E-E firms' knowledge acquisition from an advanced IJV partner will have a positive effect on their financial performance.

Hypothesis 1-1. E-E firms' knowledge acquisition from an advanced IJV partner will have a positive effect on their growth.

Hypothesis 1-2. E-E firms' knowledge acquisition from an advanced IJV partner will have a positive effect on their profitability.

\subsection{Mediation Effect of Innovation Performance}

According to the open innovation perspective, firms can pursue innovation or innovation performance by acquiring external knowledge from outside sources to gain and sustain their competitive advantage [1]. This perspective indicates that new knowledge acquired by E-E firms from an advanced IJV partners will improve their innovation or innovation performance, through which E-E firms are likely to enhance their bottom-line financial performance. Namely, it is suggested that innovation or innovation performance can serve as a mechanism connecting E-E firms' knowledge acquisition with their financial performance. Thus, we argue here that innovation performance will mediate the positive effect of E-E firms' knowledge acquisition on their financial performance (E-E firms' knowledge acquisition $\rightarrow$ E-E firms' innovation performance $\rightarrow$ E-E firms' financial performance).

First, E-E firms' knowledge acquisition from an advanced IJV partner is expected to improve their innovation performance. E-E firms will acquire tacit and explicit knowledge about product development and production, marketing and sales, and other information from an advanced IJV partner [21,24,26], and E-E firms can put such newly acquired, advanced knowledge into the process of innovation as valuable inputs, thereby enhancing their innovation performance. Furthermore, according to the secondary innovation perspective, E-E firms can escalate their innovation capabilities from duplicative imitation to creative imitation to original innovation, based on technology acquisition from an IJV partner $[37,68]$. As such, E-E firms tend to follow the two-phase innovation model $[37,69]$. Phase 1 involves creating local innovations based on imitation by acquiring mature and 
proven technologies from an IJV partner, and Phase 2 entails acquiring emerging technologies from an IJV partner in the transitional stage and involves building capabilities to create original innovation that enable E-E firms to compete and catch up with incumbent industry leaders. In this manner, based on new knowledge acquired from an advanced IJV partner, E-E firms are likely to strengthen innovation capabilities, thereby improving innovation performance.

Next, it is further expected that E-E firms' innovation performance, which is the outcomes of innovation as defined above, will enhance their financial performance. The outcomes of E-E firms' innovation, based on open and secondary innovation as discussed above $[1,2,39]$, can be new technology developments, new product developments, new product introductions, and others. These outcomes of open and secondary innovation through an advanced IJV partnership can allow E-E firms to pursue either differentiation or low costs more effectively [64]. For example, new product technologies as innovation outcomes are likely to enable E-E firms to make their new products look more unique in the eyes of potential customers, and new process technologies as innovation outcomes tend to enable E-E firms to lower their costs of production. Furthermore, enhanced product differentiation allows E-E firms either to charge premium for their products, since potential customers are willing to pay more for the additional value of products, or to broaden their customer base by charging reasonable prices for their differentiated products, thereby improving their financial performance in terms of growth and profitability [65]. Similarly, low costs also enable E-E firms to have room for either reducing prices for their products to broaden their customer base or increasing margins of their products by maintaining prices for their products, thereby enhancing their financial performance with respect to sales and profits $[65,66]$.

In short, E-E firms' new knowledge acquisition from an advanced IJV partner is likely to have a positive impact on their innovation performance as a result of open and secondary innovation, which, in turn, tends to have a positive influence on their financial performance by increasing their overall sales and profits. Based on the discussions above, we proposed the following hypothesis.

Hypothesis 2. E-E firms' innovation performance will mediate the positive effect of their knowledge acquisition from an advanced IJV partner on their financial performance.

Hypothesis 2-1. E-E firms' innovation performance will mediate the positive effect of their knowledge acquisition from an advanced IJV partner on their growth.

Hypothesis 2-2. E-E firms' innovation performance will mediate the positive effect of their knowledge acquisition from an advanced IJV partner on their profitability.

\subsection{Moderated Mediation Effect of Absorptive Capacity}

On the basis of Hypothesis 2, we further argue here that absorptive capacity will moderate the positive effect of E-E firms' knowledge acquisition from an advanced IJV partner on their financial performance through innovation performance. According to the open innovation perspective, firms seek innovation or innovation performance by leveraging knowledge from external sources to gain their sustainable competitive advantages [1,2]. This suggests that, as in Hypothesis 2, E-E firms can create innovation or innovation performance, based on external knowledge from their IJV partners, through which they can improve their competitive advantage and ultimately financial performance. However, if we look into how external knowledge is converted into innovation or innovation performance more carefully, it seems clear that, based on organizational learning and knowledge creation perspectives [3,70], E-E firms' external knowledge acquisition is likely to be linked to and combined with existing internal knowledge to create new knowledge suitable for their context. This new knowledge then be leveraged to enhance their innovation or innovation performance, thereby leading to their improved financial performance. 
In other words, to create new knowledge suitable for their context, E-E firms are likely to go through the process of combining external knowledge acquired from their IJV partner with existing internal knowledge, and E-E firms' absorptive capacity can play an important role in this process. As suggested by Cohen and Levinthal [41] and Zahra and George [42], E-E firms with higher absorptive capacity tend to have a greater ability to assimilate and combine external knowledge with existing internal knowledge to create and utilize new knowledge appropriate for their context once external knowledge is obtained. This implies that the extent to which E-E firms' external knowledge from their IJV partner is converted to innovation or innovation performance can vary depending on their absorptive capacity. When E-E firms have higher absorption capacity, their external knowledge from an IJV partner can be converted into a higher level of new knowledge or innovation or innovation performance through active combination with internal knowledge, thereby resulting in a higher level of their financial performance in terms of sales and profits. On the contrary, when E-E firms have lower absorptive capacity, their external knowledge from an advanced IJV partner cannot be converted as much into new knowledge or innovation or innovation performance, thereby resulting in a lower level of their financial performance.

In sum, the positive impact of E-E firms' knowledge acquisition from an IJV partner on their innovation or innovation performance is expected to be stronger for E-E firms with higher absorptive capacity than for those with lower absorptive capacity. Moreover, such differences in the level of E-E firms' innovation performance are likely to have a different impact on their financial performance in terms of growth and profitability. Based on these discussions, the following hypothesis was proposed.

Hypothesis 3. The positive effect of E-E firms' knowledge acquisition from an advanced IJV partner on their financial performance through innovation performance will be stronger for E-E firms with higher absorptive capacity than for those with lower absorptive capacity.

Hypothesis 3-1. The positive effect of E-E firms' knowledge acquisition from an advanced IJV partner on their growth through innovation performance will be stronger for E-E firms with higher absorptive capacity than for those with lower absorptive capacity.

Hypothesis 3-2. The positive effect of E-E firms' knowledge acquisition from an advanced IJV partner on their profitability through innovation performance will be stronger for E-E firms with higher absorptive capacity than for those with lower absorptive capacity.

\section{Research Method}

\subsection{Sample and Data Collection}

For our empirical investigation, we selected as the target population of our study Thai local firms that had established an IJV in the manufacturing sector of Thailand with 1 overseas partner from the US, Japan, or Korea only. The reason was that local firms in Thailand, an important emerging economy in Asia, would have a sufficient motivation to acquire knowledge from an advanced overseas partner by forming an IJV. Furthermore, we focused on Thai local firms whose IJV partnership with an advanced overseas partner had lasted at least for 3 years. To make up the target population of our study, we relied on information provided by the Department of International Trade Promotion of Thailand, the Department of Business Development of Thailand, the Stock Exchange of Thailand, and the Korea Trade and Investment Promotion Agency.

We collected data through surveys to test our hypotheses. For this purpose, we first drafted a questionnaire ourselves in Korean based on measures adapted or adopted from the relevant literature, and 1 of the authors and another expert who were fluent in both Korean and Thai translated the questionnaire into Thai and the Thai version back into Korean to ensure conceptual equivalence. Then, an interview-based pretest of the questionnaire was conducted with 7 CEOs of local Thai firms in the relevant industries to assess the appropriateness and clarity of the questions. The questionnaire was further 
revised based on their feedbacks. Prior to mailing out the finalized questionnaire, we contacted our target firms by phone to confirm the contact information of our target respondents, and we also explained the purpose of our research and asked for participating in our survey. We chose the heads of our target firms as our target respondents since we needed a general management perspective for more accurate information about their knowledge acquisition from an advanced IJV partner, absorptive capacity, innovation performance, and financial performance. At the end of this process, 693 firms remained as the effective target population of our study. Based on Nunnally [71], we mailed out the first-round questionnaire to the heads of these firms, followed by phone calls to ask for their participation in the survey. In the same manner, we mailed out the second-, third-, and fourth-round questionnaires with intervals of 3 weeks to those who had not replied. When necessary, we also relied on emails, faxes, and personal visits to collect responses. As a result of these efforts, we collected 127 usable response with an effective response rate of $18.3 \%$, which is certainly comparable to that of previous studies [72].

The sample of our study consisted of 50 firms with a Japanese IJV partner, 39 firms with a Korean IJV partner, and 38 firms with a US IJV partner. Our sample was distributed across 9 industries, including machinery and equipment (37.0\%), rubber and plastics $(30.7 \%)$, automotive and parts $(13.4 \%)$, electronics and electrical equipment $(11.8 \%)$, apparel and textile $(2.4 \%)$, pharmaceutical and medical $(1.6 \%)$, metals $(1.6 \%)$, steel $(0.8 \%)$, and other (0.8\%). In our sample, firms with below 1000, 1000-2000, and over 2000 employees accounted for $37.8 \%, 45.7 \%$, and $16.5 \%$, respectively. In addition, our respondents held the positions of CEOs/Presidents (20.5\%), Vice Presidents/Directors (30.7\%), Functional Managers (32.3\%), and Assistant Managers and below (16.5\%), and they had been in their positions for approximately 5 years on average.

To check for nonresponse bias, we compared the characteristics of early and late respondents based on Bodlaj and Cater [72]. Early respondents were those who replied to the first-round questionnaire, while late respondents were those who replied to the second-, third-, and fourth-round questionnaires. We found no significant differences between the 2 groups in terms of firm age $(p=0.142)$, total sales $(p=0.540)$, and employees $(p=0.271)$, implying that no serious potential nonresponse bias existed in our study.

\subsection{Measurement}

\subsubsection{Dependent Variable: Financial Performance}

Given that firms' financial performance is a multidimensional construct [55], we measured it in terms of 2 important dimensions: Growth and profitability. Following Kim, Park, and Prescott [73] and Morrison and Roth [74], firms' growth was measured by the average annual sales growth rate over the past 2 years, and firms' profitability was measured by the average annual return on sales over the past 2 years. For this measure, our respondents were asked to provide their firm's average annual sales growth rate and return on sales over the past 2 years in our survey questionnaire.

\subsubsection{Independent Variable: Knowledge Acquisition}

E-E firms' knowledge acquisition from an advanced IJV partner refers to the extent to which E-E firms have acquired knowledge from an IJV partner. Based on previous studies $[10,47]$, we relied on multiple items to measure this variable. In our survey questionnaire, using a 7-point Likert scale, we asked our respondents to indicate $(1=$ "very low" to 7 = "very high") the level in which their firms acquired knowledge about each of the following items from their IJV partner: (1) Knowledge about products and new product development, (2) knowledge about manufacturing and manufacturing process, (3) knowledge about marketing and sales, (4) knowledge about general business management, and (5) knowledge needed by their firms. 


\subsubsection{Mediation Variable: Innovation Performance}

E-E Firms' innovation performance, the mediation variable in our study, can be defined as the outcomes of innovation that can appear in the form of sales increase due to new product launches [59]. So, following Laursen and Salter [2], we measured E-E firms' innovation performance in our study by the ratio of their new product sales to total revenues. To measure this variable, we asked our respondents to provide the approximate percentage of their firm's total revenues contributed by the sales of new products released in the last 3 years in our survey questionnaire.

\subsubsection{Moderation Variable: Absorptive Capacity}

Absorptive capacity refers to firms' ability to recognize the value of external knowledge, assimilate it, and exploit it for commercial purposes [41]. Following Cohen and Levinthal [41], we measured E-E firms' absorptive capacity in this study by their R\&D intensity, which was defined by the ratio of their R\&D investment to total revenues. For this measure, our survey respondents were asked to indicate the approximate proportion of R\&D expenses to their firm's total revenues in our questionnaire.

\subsubsection{Control Variables}

We controlled for several environmental and organizational factors that would potentially have an influence on innovation and financial performance. Given that firms' innovation and financial performance tend to vary depending on the characteristics of industry $[75,76]$, we controlled the effects of industry type on innovation and financial performance and coded high-tech industries as 1 and low-tech industries as 0 [77]. In addition, firm size may influence firms' willingness to invest in innovation and account for performance differences among firms [78], so firm size was controlled and measured by the natural logarithm of the number of employees. Similarly, since older firms are likely to have a larger cumulative knowledge base in their organizations for improved innovation and performance than younger firms [79], we controlled firm age and measured it by the number of years of operation [80]. Besides, firms' experience of participating in an IJV may enable firms to pursue a higher level of innovation and performance, so we controlled for IJV experience in this study, which was dummy coded 1 for a firm with IJV experience and 0 for a firm without IJV experience [81].

\section{Results}

\subsection{Method of Analysis}

We conducted a moderated mediation analysis in our study based on the ordinary least squares (OLS) regression-based path analysis using SPSS 25 [82] (Armonk, NY, USA) and PROCESS macro v. 3.14 [83] This approach allowed us to integrate both mediation and moderation models into a unified analytical model to test each model's effect in accordance with causal steps.

We applied the bootstrap confidence interval approach to test the statistical significance of indirect effects (mediation effect) $[83,84]$ by calculating the lower limit (LLCI) and upper limit (ULCCI) of a 95\% bootstrap confidence interval for indirect effects using 5000 bootstrap samples. For moderation analysis, all relevant variables were standardized to minimize a potential collinearity problem [85].

\subsection{Validity and Reliability Tests}

Prior to conducting analyses, we performed an exploratory factor analysis based on the principal components extraction and the varimax rotation technique to assess the validity of the E-E firms' knowledge acquisition scale incorporated in our study [86]. Principal components analysis demonstrated that all items loaded on a single factor had an eigenvalue of 3.58 and accounted for 71.7 percent of the variance. We also checked the reliability of the measure using Cronbach's alpha value. The Cronbach's alpha value for 
E-E firms' knowledge acquisition construct was 0.904 , which is higher than the minimum threshold value of 0.7 [87], indicating high internal consistency.

\subsection{Descriptive Statistics and Correlations}

Table 1 depicts means, standard deviations, and correlations among the variables. There was a strong, positive correlation between E-E firms' knowledge acquisition and their financial performance (both growth and profitability). Further, E-E firms' absorptive capacity was significantly and positively correlated with their innovation performance and financial performance, respectively. We also assessed the variance inflation factor (VIF) for each of the regression equations to examine presence of multicollinearity. The VIF values in the models ranged from 1.05-2.14, which were below the cutoff value of 10 .

Table 1. Descriptive statistics and correlation matrix $(n=127)$.

\begin{tabular}{|c|c|c|c|c|c|c|c|c|c|c|c|}
\hline Variables & Mean & SD & 1 & 2 & 3 & 4 & 5 & 6 & 7 & 8 & 9 \\
\hline 1. Sales Growth & 9.61 & 8.47 & 1 & & & & & & & & \\
\hline 2. Return on Sales & 7.02 & 7.29 & $0.965 * *$ & 1 & & & & & & & \\
\hline 3. Knowledge Acquisition & 0.00 & 1.00 & $0.763 * *$ & $0.689 * *$ & 1 & & & & & & \\
\hline 4. Innovation Performance & 24.27 & 19.79 & $0.603 * *$ & $0.529 * *$ & $0.585^{* *}$ & 1 & & & & & \\
\hline 5. Absorptive Capacity & 0.00 & 1.00 & $0.627 * *$ & $0.562 * *$ & $0.647 * *$ & $0.698 * *$ & 1 & & & & \\
\hline 6. Firm size $(\log )$ & 7.07 & 0.47 & $0.228 *$ & $0.218 *$ & 0.146 & 0.114 & $0.180 *$ & 1 & & & \\
\hline 7. Firm age & 10.59 & 8.22 & -0.027 & -0.022 & 0.042 & -0.005 & 0.120 & 0.096 & 1 & & \\
\hline 8. Industry Type & 0.66 & 0.48 & -0.051 & -0.078 & -0.101 & -0.032 & -0.064 & -0.125 & -0.148 & 1 & \\
\hline 9. IJV Experience & 0.87 & 0.33 & $0.519 * *$ & $0.437 * *$ & $0.589 * *$ & $0.420 * *$ & $0.571^{* *}$ & $0.212 *$ & $0.187^{*}$ & -0.171 & 1 \\
\hline
\end{tabular}

SD: Standard Deviation; ${ }^{*} p<0.05 ;{ }^{* *} p<0.01$.

\subsection{Tests of Hypotheses}

\subsubsection{Mediation Analysis}

Table 2 presents the results of the hierarchical multiple regression analysis performed to investigate the effects of mediation (indirect effect), moderation (conditional effect), and moderated mediation (conditional indirect effect) presented in the hypotheses. The baseline model, Model 1, which includes all the control variables, reveals that, among various control variables, 'IJV experience' $(b=13.266, p<0.001)$ had a significant and positive relationship with E-E firms' financial performance measured by sales growth, and firm size $(b=2.405, p<0.1)$ had a marginally significant and positive impact on sales growth.

Model 2 in Table 2 shows the results of the regression analysis performed to investigate the direct effect of E-E firms' knowledge acquisition on their financial performance in terms of sales growth. The results show that the coefficient for E-E firms' knowledge acquisition ( $b=5.820, p<0.001)$ was positive and significant, thereby supporting Hypothesis $1-1$. In Models 4 and 6 , the results of the regression analysis conducted to examine the mediation effects of innovation performance on the relationship between E-E firms' knowledge acquisition and their sales growth are provided. The findings in Model 4, as reported in Table 2, show that E-E firms' knowledge acquisition had a significantly positive effect on their innovation performance $(b=10.103, p<0.001)$. In Model 6 , the effect of E-E firms' innovation performance on their sales growth was also significant and positive $(b=0.094, p<0.01)$ after controlling the effect of knowledge acquisition on sales growth $(b=4.869, p<0.001)$.

In addition, Table 3 reports the results of the bootstrap significance tests for total, indirect, and direct effects, respectively. The total effect $(b=5.820, C I=4.635-7.005)$, indirect effect $(b=0.951, C I=0.446-1.613)$, and direct effect $(b=4.869, C I=3.587-6.151)$ were all significant and positive, and these results are consistent with the findings from regression analyses. Taken together, these results confirm that E-E firms' innovation performance "partially" mediates the positive effect of their knowledge acquisition from an advanced IJV partner on their sales growth because the direct effect of E-E firms' knowledge acquisition was still significant. Therefore, Hypothesis 2-1 was finally supported. 
Table 2. Hierarchical multiple regression for sales growth and innovation performance $(n=127)$.

\begin{tabular}{|c|c|c|c|c|c|c|}
\hline \multirow[b]{2}{*}{ Variables } & \multicolumn{3}{|c|}{ Sales Growth } & \multicolumn{2}{|c|}{ Innovation Performance } & \multirow{2}{*}{$\begin{array}{c}\text { Sales Growth } \\
\text { Model } 6 \\
\text { B }\end{array}$} \\
\hline & $\begin{array}{l}\text { Model } 1 \\
\text { B }\end{array}$ & $\begin{array}{c}\text { Model } 2 \\
\text { B }\end{array}$ & $\begin{array}{l}\text { Model } 3 \\
\text { B }\end{array}$ & $\begin{array}{l}\text { Model } 4 \\
\text { B }\end{array}$ & $\begin{array}{c}\text { Model } 5 \\
\text { B }\end{array}$ & \\
\hline Firm size (log) & $\begin{array}{l}2.405+ \\
(1.392)\end{array}$ & $\begin{array}{l}2.082 * \\
(1.047)\end{array}$ & $\begin{array}{l}1.830+ \\
(1.026)\end{array}$ & $\begin{array}{c}0.855 \\
(3.143)\end{array}$ & $\begin{array}{l}-0.778 \\
(2.672)\end{array}$ & $\begin{array}{l}2.002 * \\
(1.009)\end{array}$ \\
\hline Firm age & $\begin{array}{c}-0.136+ \\
(0.080)\end{array}$ & $\begin{array}{l}-0.085 \\
(0.060)\end{array}$ & $\begin{array}{l}-0.094 \\
(0.059)\end{array}$ & $\begin{array}{l}-0.114 \\
(0.181)\end{array}$ & $\begin{array}{l}-0.174 \\
(0.154)\end{array}$ & $\begin{array}{l}-0.074 \\
(0.058)\end{array}$ \\
\hline Industry Type & $\begin{array}{c}0.635 \\
(1.383)\end{array}$ & $\begin{array}{c}0.707 \\
(1.040)\end{array}$ & $\begin{array}{c}0.598 \\
(1.019)\end{array}$ & $\begin{array}{l}1.533 \\
(3.112)\end{array}$ & $\begin{array}{c}0.869 \\
(2.654)\end{array}$ & $\begin{array}{c}0.563 \\
(1.003)\end{array}$ \\
\hline IJV Experience & $\begin{array}{l}13.266^{* * *} \\
(2.013)\end{array}$ & $\begin{array}{c}2.854 \\
(1.855)\end{array}$ & $\begin{array}{l}2.099 \\
(2.062)\end{array}$ & $\begin{array}{c}7.759 \\
(5.566)\end{array}$ & $\begin{array}{c}3.350 \\
(5.371)\end{array}$ & $\begin{array}{c}2.123 \\
(1.801)\end{array}$ \\
\hline Knowledge Acquisition & & $\begin{array}{c}5.820^{* * *} \\
(0.599)\end{array}$ & $\begin{array}{c}5.122 * * * \\
(0.685)\end{array}$ & $\begin{array}{c}10.103^{* * *} \\
(1.796)\end{array}$ & $\begin{array}{l}5.753 \text { ** } \\
(1.785)\end{array}$ & $\begin{array}{c}4.869 * * * \\
(0.648)\end{array}$ \\
\hline Innovation Performance & & & & & & $\begin{array}{l}0.094^{* *} \\
(0.029)\end{array}$ \\
\hline Absorptive Capacity & & & $\begin{array}{l}1.735^{*} \\
(0.654)\end{array}$ & & $\begin{array}{l}10.985^{* * *} \\
(1.703)\end{array}$ & \\
\hline $\begin{array}{c}\text { Knowledge Acquisition } x \\
\text { Absorptive Capacity }\end{array}$ & & & $\begin{array}{c}0.495 \\
(0.566)\end{array}$ & & $\begin{array}{l}3.404^{*} \\
(1.474)\end{array}$ & \\
\hline F-Statistics & $13.274^{* * *}$ & $37.674^{* * *}$ & $29.487^{* * *}$ & $13.300 * * *$ & $20.382^{* * *}$ & $35.571^{* * *}$ \\
\hline $\mathrm{R}^{2}$ & 0.303 & 0.609 & 0.634 & 0.355 & 0.545 & 0.640 \\
\hline Adjusted $\mathrm{R}^{2}$ & 0.280 & 0.593 & 0.613 & 0.328 & 0.518 & 0.622 \\
\hline Changes in $\mathrm{R}^{2}$ & & $0.306^{* * *}$ & $0.025 *$ & & $0.191^{* * *}$ & \\
\hline
\end{tabular}

Note: The table provides parameter estimates; standard errors are in parentheses. ${ }^{* * *} p<0.001,{ }^{* *} p<0.01,{ }^{*} p<0.05,+p<0.10$.

Table 3. Bootstrap significance test for total, direct, and indirect effects of emerging-economy firms' (E-E firms) knowledge acquisition on sales growth.

\begin{tabular}{ccccc}
\hline Path & \multirow{2}{*}{ Effect (b) } & \multirow{2}{*}{ Boot SE } & \multicolumn{2}{c}{ Boot 95\% CI } \\
& & LLCI & ULCI \\
\hline Total Effect of knowledge acquisition on sales growth & 5.820 & 0.599 & 4.635 & 7.005 \\
$\begin{array}{c}\text { Direct Effect of knowledge acquisition on sales growth } \\
\text { Indirect Effect of knowledge acquisition on sales growth }\end{array}$ & 4.869 & 0.648 & 3.587 & 6.151 \\
(knowledge acquisition-innovation performance-Sales Growth) & 0.951 & 0.296 & 0.446 & 1.613 \\
\hline
\end{tabular}

\subsubsection{Moderated Mediation Analysis}

Hypothesis 3-1 posits that the positive effect of E-E firms' knowledge acquisition from an IJV partner on their sales growth through innovation performance varies depending on the level of their absorptive capacity, and this points to the need for a moderated mediation analysis [83]. As the moderated mediation model is grounded on the assumption that the moderating effect should occur only in indirect paths $[88,89]$, we first tested whether the interaction effect of E-E firms' knowledge acquisition and absorptive capacity on sales growth is positive and significant. Since the interaction effect in the direct path was not significant $(b=0.495, p>0.05)$, as shown in Model 3 in Table 2, the first criterion of the moderated mediation was met.

We then examined how the positive effect of E-E firms' knowledge acquisition on innovation performance varies depending on the level of their absorptive capacity. The interaction term had a significantly positive impact $(b=3.404, p<0.05)$ on innovation performance as shown in Model 5 in Table 2. These results show that E-E firms' absorptive capacity did not affect the direct relationship between knowledge acquisition and sales growth, while it did affect the relationship between knowledge acquisition and innovation performance. These results are coherent with claims of existing research that absorptive capacity enables firms to transform or convert externally acquired knowledge into new knowledge for innovation performance or outcomes [41]. 
Additionally, we examined how the positive effect of E-E firms' knowledge acquisition from an advanced IJV partner on innovation performance varies depending on the level of their absorptive capacity by applying the Johnson-Neyman (JN) technique [90]. The point of transition (z-score of absorptive capacity) that demarcates the regions where the interaction effects are significant and not significant was $-0.647(\mathrm{M}=-0.647)$. When $\mathrm{M}>-0.647$ (JNM1), the positive effect of E-E firms' knowledge acquisition on innovation performance was significant, but it was not significant when $M<-0.647$. That is, the effect of E-E firms' knowledge acquisition on innovation performance was significant and positive among E-E firms which have a high level of absorptive capacity $(\mathrm{M}>-0.647)$ but not significant among E-E firms which have a low level of absorptive capacity $(\mathrm{M}<-0.647)$. Figure 2 is the JN plot that presents the conditional effect of E-E firms' knowledge acquisition on innovation performance at different levels of absorptive capacity.

Last, we examined the statistical significance of the conditional indirect effect to determine how the indirect effect (mediation effect of innovation performance) varies depending on different levels of absorptive capacity (+1 SD, 0, $-1 \mathrm{SD}$ ) by testing for bootstrap significance for moderated mediation (Table 4). As reported in Table 4, the indirect effects were different across varying levels of absorptive capacity. The indirect effect was significant and positive in the group with medium absorptive capacity $(b=0.542$, $\mathrm{CI}=0.162-1.087)$ and high absorptive capacity $(\mathrm{b}=0.862, \mathrm{CI}=0.263-1.786)$ but was not significant in the group with low absorptive capacity $(\mathrm{b}=0.221, \mathrm{CI}=-0.047-0.620)$. Therefore, Hypothesis 3-1 was finally supported.

Our results suggest that even among E-E firms that acquire knowledge from their IJV partner, those with high absorptive capacity are likely to produce higher innovation performance, which, subsequently, has a positive impact on their sales growth. These results are consistent with the findings in the knowledge management literature. That is, the efficiency of knowledge creation is determined by the degree of interactions between external knowledge acquisition and internal learning or knowledge-generating capabilities [91,92].

Furthermore, we obtained quite similar results in an additional moderated mediation analysis conducted by adopting return on sales (ROS) as an alternative dependent variable (see Tables A1-A3 in Appendix A), thereby supporting Hypotheses 1-2, 2-2, and 3-2. Based on all these results, we therefore conclude that all the hypotheses proposed in our study were supported. A summary of the hypotheses testing results is listed in Table 5.
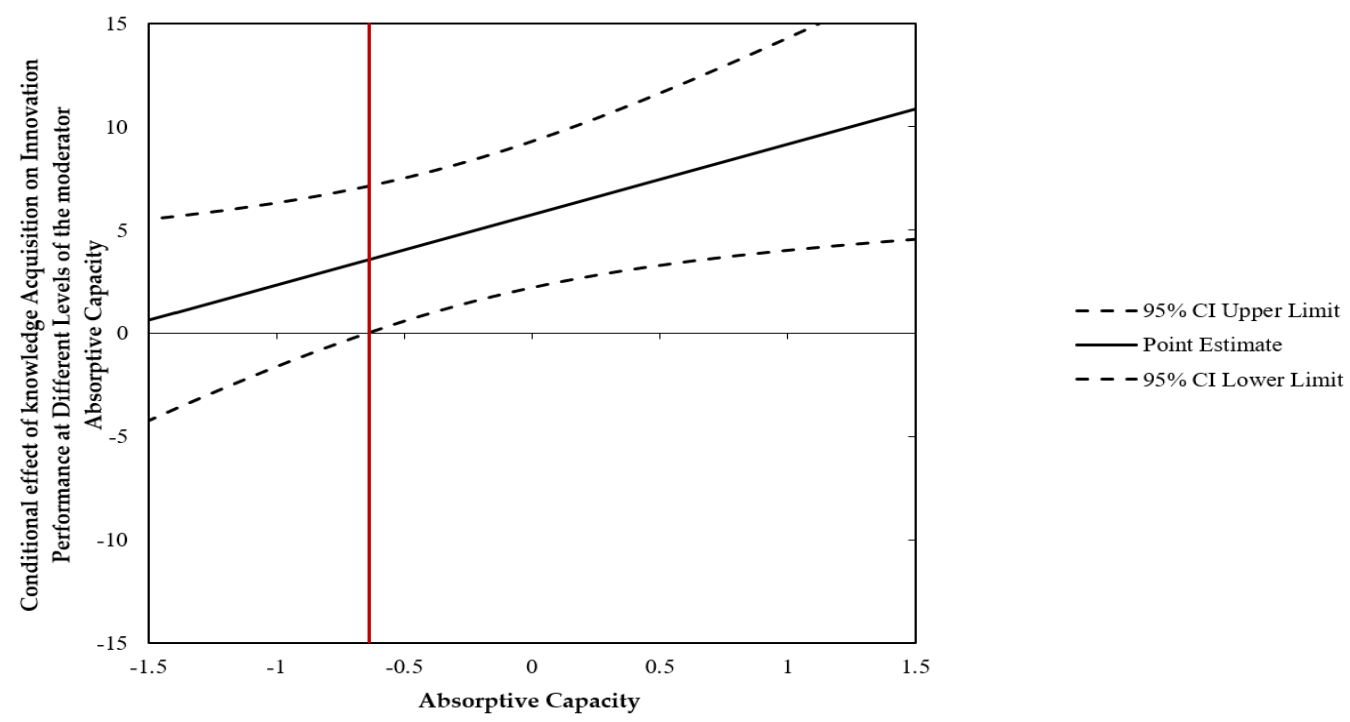

Figure 2. Conditional effect of E-E firms' knowledge acquisition on innovation performance as a function of absorptive capacity. 
Table 4. Bootstrap significance test for the conditional indirect effect of knowledge acquisition on sales growth through innovation performance at different levels of absorptive capacity.

\begin{tabular}{cccccc}
\hline Mediator & $\begin{array}{c}\text { Moderator } \\
\text { (Absorptive Capacity) }\end{array}$ & Conditional Indirect Effects & Boot SE & Boot LLCI & Boot ULCI \\
\hline \multirow{2}{*}{ Innovation } & $-1.000(-1 \mathrm{SD})$ & 0.221 & 0.164 & -0.047 & 0.620 \\
Performance & $0.000($ mean) & 0.542 & 0.235 & 0.162 & 1.087 \\
& $1.000(+1 \mathrm{SD})$ & 0.862 & 0.379 & 0.263 & 1.786 \\
\hline
\end{tabular}

Table 5. Summary of hypotheses and empirical conclusions.

\begin{tabular}{|c|c|c|}
\hline Hypothesis & Expected Sign & Empirical Conclusions \\
\hline $\begin{array}{l}\text { Hypothesis } 1 . \text { E-E firms' knowledge acquisition from an advanced IJV partner will have } \\
\text { a positive effect on their financial performance. }\end{array}$ & + & Supported \\
\hline $\begin{array}{l}\text { Hypothesis 1-1. E-E firms' knowledge acquisition from an advanced IJV partner will } \\
\text { have a positive effect on their growth. }\end{array}$ & + & Supported \\
\hline $\begin{array}{l}\text { Hypothesis 1-2. E-E firms' knowledge acquisition from an advanced IJV partner will } \\
\text { have a positive effect on their profitability. }\end{array}$ & + & Supported \\
\hline $\begin{array}{l}\text { Hypothesis 2. E-E firms' innovation performance will mediate the positive effect of their } \\
\text { knowledge acquisition from an advanced IJV partner on their financial performance. }\end{array}$ & + & Supported \\
\hline $\begin{array}{l}\text { Hypothesis 2-1. E-E firms' innovation performance will mediate the positive effect of } \\
\text { their knowledge acquisition from an advanced IJV partner on their growth. }\end{array}$ & + & Supported \\
\hline $\begin{array}{l}\text { Hypothesis 2-2. E-E firms' innovation performance will mediate the positive effect of } \\
\text { their knowledge acquisition from an advanced IJV partner on their profitability. }\end{array}$ & + & Supported \\
\hline $\begin{array}{l}\text { Hypothesis 3. The positive effect of E-E firms' knowledge acquisition from an advanced } \\
\text { IJV partner on their financial performance through innovation performance will be stronger } \\
\text { for E-E firms with higher absorptive capacity than for those with lower absorptive capacity. }\end{array}$ & + & Supported \\
\hline $\begin{array}{l}\text { Hypothesis 3-1. The positive effect of E-E firms' knowledge acquisition from an } \\
\text { advanced IJV partner on their growth through innovation performance will be stronger for } \\
\text { E-E firms with higher absorptive capacity than for those with lower absorptive capacity. }\end{array}$ & + & Supported \\
\hline $\begin{array}{l}\text { Hypothesis 3-2. The positive effect of E-E firms' knowledge acquisition from an advanced } \\
\text { IJV partner on their profitability through innovation performance will be stronger for E-E } \\
\text { firms with higher absorptive capacity than for those with lower absorptive capacity. }\end{array}$ & + & Supported \\
\hline
\end{tabular}

\section{Conclusions and Discussions}

\subsection{Conclusions}

To create and sustain competitive advantage, firms today are expected to rely on external knowledge on top of existing internal knowledge $[1,70,93,94]$. In this sense, E-E firms are particularly likely to have a great need to pursue open innovation by acquiring external knowledge through their IJV partnership with an advanced foreign partner for their sustainable competitive advantage, since they tend to have a relatively weak internal knowledge base. Hence, the issue of E-E firms' knowledge acquisition for innovation from their advanced foreign partner through an IJV has gained an increasing attention from researchers. However, the literature has focused primarily on examining the antecedents or determinants of E-E firms' knowledge acquisition from their IJV partner, and, surprisingly, it has largely ignored investigating the performance implications of E-E firms' knowledge acquisition from their IJV partner.

To fill this important gap in the literature, we addressed the following three issues related to understanding the relationship between E-E firms' knowledge acquisition from an advanced IJV partner and their financial performance more completely: Whether, how (through what mechanism), and when (under what condition) E-E firms' knowledge acquisition from an advanced IJV partner has a positive impact on their financial performance. Drawing on open innovation and organizational learning perspectives, we empirically ex- 
amined the effect of E-E firms' knowledge acquisition from an IJV partner on their financial performance and investigated both a pathway (innovation performance) and a condition (absorptive capacity) that influence the relationship between E-E firms' knowledge acquisition from an IJV partner and their financial performance.

Based on a sample of 127 Thai manufacturing firms that formed an IJV with an advanced foreign partner, the results of our moderated mediation analysis reveal that E-E firms' knowledge acquisition from an IJV partner has a positive impact on their financial performance in terms of both sales growth and return on sales. More importantly, it is found that E-E firms' innovation performance plays a critical role as a mediator that links the E-E firms' knowledge acquisition-financial performance relationship. Consistent with the arguments in prior studies $[12,41,42,63,95]$, our empirical results further demonstrate that E-E firms' absorptive capacity works as a moderator that plays an important part in converting external knowledge into innovation performance, which consequently leads to their superior financial performance. In other words, our results show that the positive effect of E-E firms' knowledge acquisition from an IJV partner on their innovation performance is stronger for E-E firms with higher absorptive capacity than for those with lower absorptive capacity. Taken together, our results provide strong evidence that, although E-E firms' knowledge acquisition from an IJV partner is a necessary condition for explaining their financial success, it may not be a sufficient condition for explaining their financial success without considering both a mediation effect of their innovation performance and a moderated mediation effect of their absorptive capacity.

\subsection{Implications}

Our study makes important theoretical contributions to the literature by providing clear and initial empirical evidence on whether, how, and when interfirm differences in financial performance in terms of sales growth and return on sales arise among E-E firms acquiring knowledge for innovation from their advanced IJV partner. First, our study addressed the "whether" issue by empirically demonstrating a positive impact of E-E firms' knowledge acquisition from an IJV partner on their financial performance, thereby validating an implicit assumption or premise in the literature. Second, our study dealt with the "how" issue by showing an important role of (open and secondary) innovation performance as an explicit pathway through which E-E firms' knowledge acquisition from an IJV partner can improve their financial performance. Our results imply that open innovation strategy, aimed at leveraging external knowledge to create firms' own innovation or innovation performance, is no longer exclusive to firms in a developed economy and serves as an important vehicle through which E-E firms can improve their financial performance. Third, our study addressed the "when" issue by revealing strong empirical evidence that absorptive capacity is a key moderator in the relationship between E-E firms' knowledge acquisition and their innovation performance. Our results indicate that even among firms that have acquired a large amount of knowledge from their IJV partner, the positive effect of E-E firms' knowledge acquisition on their innovation performance is observed when E-E firms have a higher level of absorptive capacity. Our study shows that absorptive capacity has a significant influence on converting externally acquired knowledge into innovation or innovation performance, which, in turn, leads to superior financial performance. In agreement with previous research in organizational learning, our results indicate that the effect of E-E firms' knowledge acquisition from an IJV partner on their innovation performance depends on interfirm differences in absorptive capacity, thereby pointing to the need for balancing interorganizational collaboration (for external knowledge acquisition) and intraorganizational capability (absorptive capacity) that determine the efficiency of the knowledge-creation process $[75,91,92,95]$. 
Our study also provides some important practical implications for managers. First, our study clearly demonstrates to managers that E-E firms acquiring knowledge from an advanced IJV partner can, in fact, improve their bottom-line financial performance in terms of sales growth and return on sales. Second, our study further suggests that such E-E firms need to pay attention to open and secondary innovation strategy as a critical pathway to their superior financial success. Our study shows that E-E firms acquiring knowledge from an IJV partner can further improve their financial performance through open and secondary innovation outcomes such as new product developments and introductions to the market. Facing increasingly more turbulent and knowledge intensive environment, E-E firms with initial advantages of low costs caused by abundant labor resources need to try to move away from more labor-intensive growth to more knowledge-intensive growth to ensure their sustainable competitive advantage, since their ability to develop and introduce new products based on new knowledge becomes increasingly more important. In this sense, external knowledge acquired by E-E firms from an IJV partner becomes critical since E-E firms tends to have a relatively weak knowledge base, and this external knowledge enables them to pursue improved innovation or innovation performance by developing and introducing new products, which subsequently leads to superior financial performance. Third, our study further indicates to managers that E-E firms need to enhance their absorptive capacity, which is basically a knowledge-generating ability similar to R\&D capability [41], to convert external knowledge acquired by E-E firms from an IJV partner into new valuable knowledge and innovation or innovation outcomes effectively. In turn, enhancing their absorptive capacity leads to their improved financial performance. E-E firms generally acquire mature technologies from IJV partners in advanced economies to reduce risks associated with investing in innovation, but these technologies tend to become obsolete with the emergence of new technologies, making E-E firms fall behind again [38]. Therefore, in-house R\&D efforts become essential for E-E firms to upgrade these technologies and apply them for practical use. Firms' R\&D investment plays a significant role in determining their absorptive capacity [2], since knowledge accumulated through internal R\&D can contribute to creating 'new knowledge' by allowing firms to recognize, assimilate, and apply new valuable knowledge beyond their organizational boundaries and to commercial ends effectively. Hence, E-E firms need to make assiduous efforts to improve absorptive capacity by increasing investment in their in-house R\&D. E-E firms also need to increase interfirm learning from their IJV partner, since the interactions between external and internal learning processes lies at the center of knowledge creation processes [42].

\subsection{Limitations and Future Research}

Our study has several limitations that could lead to further research. First, since the context of our study focused on Thai emerging-economy manufacturing firms involved in their IJV partnership with an advanced overseas partner, the results of our study may not be generalizable beyond our research context. So, it appears to be necessary for future research to assess the generalizability of our results by enlarging its research context to a broader scope of industries, geographies, and firms (including advanced-economy firms). Second, our results revealed that E-E firms' innovation performance partially mediated the effect of their knowledge acquisition from an advanced IJV partner on their sales growth and return on sales. This finding further suggests the need to explore different causal pathways through which E-E firms' knowledge acquisition from an IJV partner influences their financial performance. By extending our research model, future research comparing different indirect effects in multiple mediator models may shed additional light on the complex processes through which E-E firms benefit from acquiring external knowledge through an IJV. Third, in a similar vein, although our study examined the role of abortive capacity as E-E firms' internal capability that would influence the E-E firms' knowledge acquisition-innovation performance relationship, external factors such as environmental dynamism and product life cycle might also affect the proposed relationship. Therefore, it seems desirable for future studies to examine other relevant factors as moderators that may 
affect the E-E firms' knowledge acquisition-innovation performance relationship. Fourth, although we did not classify knowledge acquired by E-E firms from their IJV partner into different types in our study, different types of knowledge might have varying degrees of influence on innovation and financial performance. So, future studies should take this into consideration to provide some additional insight to the literature. Last, since we took a cross-sectional research approach in this study, we were not able to investigate whether and how the effects of E-E firms' knowledge acquisition from an IJV partner on their shortand long-term innovation and financial performance might evolve over time. So, future studies should try to take a longitudinal approach to be able to deal with this limitation.

Author Contributions: Conceptualization: C.Y.K. and E.-H.S.; methodology: E.-H.S. and K.K.; data collection: C.B.; Analysis: C.Y.K.; validation: E.-H.S.; writing: C.Y.K. and E.-H.S.; reviewing and editing: K.K.; revision and resubmission process: C.Y.K. and K.K. All authors have read and agreed to the published version of the manuscript.

Funding: This research received no external funding.

Institutional Review Board Statement: Not applicable.

Informed Consent Statement: Not applicable.

Data Availability Statement: Not applicable.

Conflicts of Interest: The authors declare no conflict of interest.

\section{Appendix A}

Table A1. Hierarchical multiple regression for return on sales and innovation performance.

\begin{tabular}{|c|c|c|c|c|c|c|}
\hline \multirow{3}{*}{ Variables } & \multicolumn{3}{|c|}{ Return on Sales } & \multicolumn{2}{|c|}{ Innovation Performance } & \multirow{2}{*}{$\begin{array}{c}\text { Return on Sales } \\
\text { Model } 6\end{array}$} \\
\hline & Model 1 & Model 2 & Model 3 & Model 4 & Model 5 & \\
\hline & B & B & B & B & B & B \\
\hline Firm size $(\log ))$ & $\begin{array}{l}2.114+ \\
(1.267)\end{array}$ & $\begin{array}{l}1.852 \dagger \\
(1.026)\end{array}$ & $\begin{array}{c}1.645 \\
(1.015)\end{array}$ & $\begin{array}{c}0.855 \\
(3.143)\end{array}$ & $\begin{array}{l}-0.778 \\
(2.672)\end{array}$ & $\begin{array}{l}1.794+ \\
(1.008)\end{array}$ \\
\hline Firm age & $\begin{array}{l}-0.103 \\
(0.073)\end{array}$ & $\begin{array}{l}-0.061 \\
(0.059)\end{array}$ & $\begin{array}{l}-0.069 \\
(0.058)\end{array}$ & $\begin{array}{l}-0.114 \\
(0.181)\end{array}$ & $\begin{array}{l}-0.174 \\
(0.154)\end{array}$ & $\begin{array}{l}-0.054 \\
(0.058)\end{array}$ \\
\hline Industry Type & $\begin{array}{l}-0.072 \\
(1.259)\end{array}$ & $\begin{array}{l}-0.013 \\
(1.019)\end{array}$ & $\begin{array}{l}-0.105 \\
(1.008)\end{array}$ & $\begin{array}{c}1.533 \\
(3.112)\end{array}$ & $\begin{array}{c}0.869 \\
(2.654)\end{array}$ & $\begin{array}{l}-0.116 \\
(1.002)\end{array}$ \\
\hline IJV Experience & $\begin{array}{c}9.379 * * * \\
(1.832)\end{array}$ & $\begin{array}{c}0.910 \\
(1.816)\end{array}$ & $\begin{array}{c}0.272 \\
(2.040)\end{array}$ & $\begin{array}{c}7.759 \\
(5.566)\end{array}$ & $\begin{array}{c}3.350 \\
(5.371)\end{array}$ & $\begin{array}{c}0.388 \\
(1.799)\end{array}$ \\
\hline Knowledge Acquisition & & $\begin{array}{c}4.734^{* * *} \\
(0.586)\end{array}$ & $\begin{array}{c}4.156^{* * *} \\
(0.678)\end{array}$ & $\begin{array}{c}10.090^{* * *} \\
(1.794)\end{array}$ & $\begin{array}{l}5.753^{* *} \\
(1.785)\end{array}$ & $\begin{array}{c}4.054^{* * * *} \\
(0.647)\end{array}$ \\
\hline Innovation Performance & & & & & & $\begin{array}{l}0.067^{*} \\
(0.029)\end{array}$ \\
\hline Absorptive Capacity & & & $\begin{array}{l}1.428 * \\
(0.647)\end{array}$ & & $\begin{array}{c}10.985^{* * *} \\
(1.703)\end{array}$ & \\
\hline $\begin{array}{c}\text { Knowledge Acquisition } \\
x \\
\text { Absorptive Capacity }\end{array}$ & & & $\begin{array}{c}0.395 \\
(0.560)\end{array}$ & & $\begin{array}{l}3.404 * \\
(1.474)\end{array}$ & \\
\hline F-Statistics & $8.607^{* * *}$ & $23.555 * * *$ & $18.149^{* * *}$ & $13.300 * * *$ & $20.382 * * *$ & $21.221^{* * *}$ \\
\hline $\mathrm{R}^{2}$ & 0.220 & 0.493 & 0.516 & 0.355 & 0.545 & 0.515 \\
\hline Adjusted $\mathrm{R}^{2}$ & 0.195 & 0.472 & 0.488 & 0.328 & 0.518 & 0.491 \\
\hline Changes in $\mathrm{R}^{2}$ & & $0.273^{* * *}$ & $0.023+$ & & $0.191^{* * *}$ & \\
\hline
\end{tabular}

Note: The table provides parameter estimates; standard errors are in parentheses. ${ }^{* * *} p<0.001,{ }^{* *} p<0.01,{ }^{*} p<0.05,+p<0.10$. 
Table A2. Bootstrap significance test for total, direct, and indirect effects of E-E firms' knowledge acquisition on return on sales.

\begin{tabular}{|c|c|c|c|c|}
\hline \multirow[b]{2}{*}{ Path } & \multirow{2}{*}{ Effect $(b)$} & \multirow[b]{2}{*}{ Boot SE } & \multicolumn{2}{|c|}{ Boot 95\% CI } \\
\hline & & & LLCI & ULCI \\
\hline Total Effect of knowledge acquisition on return on sales & 4.734 & 0.586 & 3.573 & 5.894 \\
\hline Direct Effect of knowledge acquisition on return on sales & 4.054 & 0.647 & 2.773 & 5.335 \\
\hline $\begin{array}{l}\text { Indirect Effect of knowledge acquisition on return on sales } \\
\text { (knowledge acquisition-innovation performance-return on sales) }\end{array}$ & 0.680 & 0.287 & 0.201 & 1.362 \\
\hline
\end{tabular}

Table A3. Bootstrap significance test for conditional indirect effect of knowledge acquisition on return on sales through innovation performance at different levels of absorptive capacity.

\begin{tabular}{cccccc}
\hline Mediator & $\begin{array}{c}\text { Moderator } \\
\text { (Absorptive Capacity) }\end{array}$ & Conditional Indirect Effects & Boot SE & Boot LLCI & Boot ULCI \\
\hline \multirow{2}{*}{ Innovation } & $-1.000(-1 \mathrm{SD})$ & 0.158 & 0.125 & -0.009 \\
Performance & $0.000($ mean) & 0.387 & 0.202 & 0.094 & 0.925 \\
& $1.000(+1 \mathrm{SD})$ & 0.616 & 0.328 & 0.148 & 1.527 \\
\hline
\end{tabular}

\section{References}

1. Chesbrough, H.W. Open Innovation: The New Imperative for Creating and Profiting from Technology; Harvard Business School Press: Boston, MA, USA, 2003.

2. Laursen, K.; Salter, A. Open for innovation: The role of openness in explaining innovation performance among U.K. manufacturing firms. Strateg. Manag. J. 2006, 27, 131-150. [CrossRef]

3. Huber, G.P. Organizational learning: The contributing processes and the literatures. Organ. Sci. 1998, 2, 1-147. [CrossRef]

4. Soto-Acosta, P.; Popa, S.; Palacios-Marqués, D. Social web knowledge sharing and innovation performance in knowledge-intensive manufacturing SMEs. J. Tech. Tran. 2017, 42, 425-440. [CrossRef]

5. Dyer, J.H.; Singh, H. The relational view: Cooperative strategy and sources of interorganizational competitive advantage. Acad. Manag. Rev. 1998, 23, 660. [CrossRef]

6. Inkpen, A.C. Learning Through Joint Ventures: A Framework of Knowledge Acquisition. J. Manag. Stud. 2000, 37, 1019-1044. [CrossRef]

7. Inkpen, A.C.; Dinur, A. Knowledge management processes and international joint ventures. Organ. Sci. 1998, 9, 454-468. [CrossRef]

8. Inkpen, A.; Minbaeva, D.; Tsang, E.W.K. Unintentional, unavoidable, and beneficial knowledge leakage from the multinational enterprise. J. Int. Bus. Stud. 2019, 50, 250-260. [CrossRef]

9. Lane, P.; Lubatkin, M. Relative absorptive capacity and interorganizational learning. Strateg. Manag. J. 1998, 19, 461-477. [CrossRef]

10. Simonin, B.L. Ambiguity and the process of knowledge transfer in strategic alliances. Strateg. Manag. J. 1999, 20, 595-623. [CrossRef]

11. Simonin, B.L. An Empirical Investigation of the Process of Knowledge Transfer in International Strategic Alliances. J. Int. Bus. Stud. 2004, 35, 407-427. [CrossRef]

12. Yun, J.J.; Lee, M.; Park, K.; Zhao, X. Open Innovation and Serial Entrepreneurs. Sustainability 2019, 11, 5055. [CrossRef]

13. Yun, J.J.; Jeong, E.; Zhao, X.; Hahm, S.D.; Kim, K. Collective Intelligence: An Emerging World in Open Innovation. Sustainability 2019, 11, 4495. [CrossRef]

14. Yun, J.; Won, D.; Park, K. Entrepreneurial cyclical dynamics of open innovation. J. Evol. Econ. 2018, 28, 1151-1174. [CrossRef]

15. Hameduddin, T.; Fernandez, S.; Demircioglu, M.A. Conditions for open innovation in public organizations: Evidence from Challenge.gov. Asia Pac. J. Publ. Adm. 2020, 42, 111-131. [CrossRef]

16. Heimstädt, M.; Reischauer, G. Framing innovation practices in interstitial issue fields: Open innovation in the NYC administration. Innov. Organ. Manag. 2018, 21, 1-23. [CrossRef]

17. Loukis, E.Y.; Charalabidis, Y.; Androutsopoulou, A. Promoting Open Innovation in the Public Sector through Social Media Monitoring. Gov. Inf. Q. 2017, 34, 99-109. [CrossRef]

18. Kogut, B. Joint ventures: Theoretical and empirical perspectives. Strateg. Manag. J. 1988, 9, 319-332. [CrossRef]

19. Mowery, D.C.; Oxley, J.E.; Silverman, B.S. Strategic alliances and interfirm knowledge transfer. Strateg. Manag. J. 1996, 17, 77-91. [CrossRef]

20. Song, J. Technological Catch-up and Knowledge Sourcing of Latecomers from Emerging Economies. AIB Insights 2016, 16, 15-17. [CrossRef]

21. Evangelista, F. Acquiring tacit and explicit marketing knowledge from foreign partners in IJVs. J. Bus. Res. 2007, 60, 1152-1165.

22. Park, C.; Vertinsky, I.; Becerra, M. Transfers of tacit vs. explicit knowledge and performance in international joint ventures: The role of age. Int. Bus. Rev. 2015, 24, 89-101. [CrossRef] 
23. Liu, J.; Cui, Z.; Feng, Y.; Perera, S.; Han, J. Impact of culture differences on performance of international construction joint ventures: The moderating role of conflict management. Eng. Constr. Archit. Manag. 2020, 27, 2353-2377. [CrossRef]

24. Ado, A.; Su, Z.; Wanjiru, R. Learning and Knowledge Transfer in Africa-China JVs: Interplay between Informalities, Culture, and Social Capital. J. Int. Manag. 2016, 23, 166-179. [CrossRef]

25. Lane, P.J.; Salk, J.E.; Lyles, M.A. Absorptive capacity, learning, and performance in international joint ventures. Strateg. Manag. J. 2001, 22, 1139-1161. [CrossRef]

26. Lin, $X$. Local partner acquisition of managerial knowledge in international joint ventures: Focusing on foreign management control. Manag. Int. Rev. 2005, 45, 219-237.

27. Pak, Y.S.; Park, Y.R. A framework of knowledge transfer in cross-border joint ventures: An empirical test of the Korean context. Manag. Int. Rev. 2004, 44, 417-434.

28. Lin, Y.; Wu, L.-Y. Exploring the role of dynamic capabilities in firm performance under the resource-based view framework. J. Bus. Res. 2014, 67, 407-413. [CrossRef]

29. Shenkar, O.; Li, J. Knowledge Search in International Cooperative Ventures. Organ. Sci. 1999, 10, 134-143. [CrossRef]

30. Szulanski, G. Exploring internal stickiness: Impediments to the transfer of best practices within the firm. Strateg. Manag. J. 1996, 17, 27-43. [CrossRef]

31. Tsang, E.W.K. A Preliminary Typology of Learning in International Strategic Alliances. J. World Bus. 1999, 34, 211-229. [CrossRef]

32. Dhanaraj, C.; Lyles, M.A.; Steensma, H.K.; Tihanyi, L. Managing tacit and explicit knowledge transfer in IJVs: The role of relational embeddedness and the impact on performance. J. Int. Bus. Stud. 2004, 35, 428-443. [CrossRef]

33. Mahmood, I.P.; Zheng, W. Whether and how: Effects of international joint ventures on local innovation in an emerging economy. Res. Policy 2009, 38, 1489-1503. [CrossRef]

34. Petti, C.; Tang, Y.; Margherita, A. Technological innovation vs. technological backwardness patterns in latecomer firms: An absorptive capacity perspective. J. Eng. Technol. Manag. 2019, 51, 10-20. [CrossRef]

35. Triki, D.; Mayrhofer, U. Do initial characteristics influence IJV longevity? Evidence from the Mediterranean region. Int. Bus. Rev. 2016, 25, 795-805. [CrossRef]

36. Seo, E.; Kang, H.; Song, J. Blending talents for innovation: Team composition for cross-border R\&D collaboration within multinational corporations. J. Int. Bus. Stud. 2020, 51, 851-885.

37. $\mathrm{Wu}, \mathrm{X}$; $\mathrm{Ma}, \mathrm{R} . ; \mathrm{Xu}, \mathrm{G}$. Accelerating secondary innovation through organizational learning: A case study and theoretical analysis. Ind. Innov. 2009, 16, 389-409. [CrossRef]

38. Wu, X.; Ma, R.; Shi, Y. How do latecomer firms capture value from disruptive technologies. A secondary business-model innovation perspective. IEEE T. Eng. Manag. 2010, 57, 51-62. [CrossRef]

39. Sinha, U.B. Imitative innovation and international joint ventures: A dynamic analysis. Int. J. Ind. Organ. 2001, 19, 1527-1562. [CrossRef]

40. Lane, P.J.; Koka, B.R.; Pathak, S. The reification of absorptive capacity: A critical review and rejuvenation of the construct. Acad. Manag. Rev. 2006, 31, 833-863. [CrossRef]

41. Cohen, W.; Levinthal, D. Innovation and learning: The two faces of R\&D. Econ. J. 1989, 99, 569-596.

42. Zahra, S.A.; George, G. Absorptive capacity: A review, reconceptualization, and extension. Acad. Manag. Rev. 2002, 27, 185-203. [CrossRef]

43. Grant, R.M. Toward a knowledge-based theory of the firm. Strateg. Manag. J. 1996, 17, 109-122. [CrossRef]

44. Hobday, M. East Asian latecomer firms: Learning the technology of electronics. World Dev. 1995, 23, 1171-1193. [CrossRef]

45. Tsang, E.W.K. Acquiring Knowledge by Foreign Partners from International Joint Ventures in a Transition Economy: Learning-byDoing and Learning Myopia. Strateg. Manag. J. 2002, 23, 835-854. [CrossRef]

46. Nonaka, I.A. Dynamic Theory of Organizational Knowledge Creation. Organ. Sci. 1994, 5, 14-37. [CrossRef]

47. Zander, U.; Kogut, B. Knowledge and the Speed of the Transfer and Imitation of Organizational Capabilities: An Empirical Test. Organ. Sci. 1995, 6, 76-92. [CrossRef]

48. Inkpen, A.C. Knowledge transfer and international joint ventures: The case of NUMMI and General motors. Strateg. Manag. J. 2008, 29, 447-453. [CrossRef]

49. Gupta, A.K.; Govindarajan, V. Knowledge flows within multinational cor-porations. Strateg. Manag. J. 2000, 21, 473-496. [CrossRef]

50. Mathrani, S.; Edwards, B. Knowledge-Sharing Strategies in Distributed Collaborative Product Development. J. Open Innov. Technol. Mark. Complex. 2020, 6, 194. [CrossRef]

51. Kale, P.; Singh, H.; Perlmutter, H. Learning and protection of proprietary assets in strategic alliances: Building relational capital. Strateg. Manag. J. 2000, 21, 217-237. [CrossRef]

52. Gulati, R.; Singh, H. The architecture of cooperation: Managing coordination costs and appropriation concerns in strategic alliances. Adm. Sci. Q. 1998, 43, 781-814. [CrossRef]

53. Birkinshaw, J.; Nobel, R.; Ridderstråle, J. Knowledge as a contingency variable: Do the characteristics of knowledge predict organization structure? Organ. Sci. 2002, 13, 274-289. [CrossRef]

54. Bowea, M.; Golesorkhib, S.; Yamin, M. Explaining equity shares in international joint ventures: Combining the influence of asset characteristics, culture and institutional differences. Res. Int. Bus. Financ. 2014, 31, 212-233. [CrossRef] 
55. Rothaermel, F.T.; Alexandre, M.T. Ambidexterity in technology sourcing: The moderating role of absorptive capacity. Organ. Sci. 2009, 20, 759-780. [CrossRef]

56. Osland, G. Successful Operating Strategies in the Performance of U.S.-China Joint Ventures. J. Int. Mark. 1994, 2, 53-78.

57. Teece, D.J. Firm organization, industrial structure, and technological innovation. J. Econ. Behav. Organ. 1996, 31, $193-224$. [CrossRef]

58. Jiménez-Jiménez, D.; Sanz-Valle, R. Innovation, organizational learning, and performance. J. Bus. Res. 2011, 64, 408-417. [CrossRef]

59. Chandy, R.K.; Tellis, G.J. The incumbent's curse? Incumbency, size, and radical product innovation. J. Mark. 2000, 64, 1-17.

60. Si, S.X.; Bruton, G.D. Knowledge acquisition, cost savings, and strategic positioning: Effects on Sino-American IJV performance. J. Bus. Res. 2005, 58, 1465-1473. [CrossRef]

61. Cullen, J.B.; Johnson, J.L.; Sakano, T. Success through commitment and trust: The soft side of strategic alliance management. J. World Bus. 2000, 35, 223-240. [CrossRef]

62. Avalos-Quispe, G.A.; Hernández-Simón, L.M. Open Innovation in SMEs: Potential and Realized Absorptive Capacity for Interorganizational Learning in Dyad Collaborations with Academia. J. Open Innov. Technol. Mark. Complex. 2019, 5, 72. [CrossRef]

63. Kim, J.; Choi, S.O. A Comparative Analysis of Corporate R\&D Capability and Innovation: Focused on the Korean Manufacturing Industry. J. Open Innov. Technol. Mark. Complex. 2020, 6, 100.

64. Hill, C.W.; Jones, G.R.; Schilling, M.A. Strategic Management: An Integrated Approach, 11th ed.; Cengage Learning: Boston, MA, USA, 2015.

65. Porter, M.E. Competitive Strategy; The Free Press: New York, NY, USA, 1980.

66. Porter, M.E. Competitive Advantage; A Division of Macmillan, Inc.: New York, NY, USA, 1985.

67. Banker, R.D.; Mashruwala, R.; Tripathy, A. Does a differentiation strategy lead to more sustainable financial performance than a cost leadership strategy? Manag. Decis. 2014, 52, 872-896. [CrossRef]

68. Kim, L. Crisis Construction and Organizational Learning: Capability Building in Catching-up at Hyundai Motors. Organ. Sci. 1998, 9, 506-521. [CrossRef]

69. Utterback, J.M.; Suárez, F.F. Innovation, competition, and industry structure. Res. Policy 1993, 22, 1-21. [CrossRef]

70. Nonaka, I.; Takeuchi, H. The Knowledge-Creating Company: How Japanese Companies Create the Dynamics of Innovation; Oxford University Press: New York, NY, USA, 1995.

71. Nunnally, J.C. Bychometric Theory, 2nd ed.; McGrow Hill: New York, NY, USA, 1978.

72. Bodlaj, M.; Cater, B. The Impact of Environmental Turbulence on the Perceived Importance of Innovation and Innovativeness in SMEs. J. Small Bus. Manag. 2019, 57, 417-435. [CrossRef]

73. Kim, K.; Park, J.H.; Prescott, J.E. The global integration of business functions: A study of multinational businesses in integrated global industries. J. Int. Bus. Stud. 2003, 34, 327-344. [CrossRef]

74. Morrison, A.J.; Roth, K. A taxonomy of business-level strategies in global industries. Strateg. Manag. J. 1992, 13, 399-418. [CrossRef]

75. Lichtenthaler, U. Absorptive capacity, environmental turbulence, and the complementarity of organizational learning processes. Acad. Manag. J. 2009, 52, 822-846. [CrossRef]

76. Sidhu, J.S.; Commandeur, H.R.; Volberda, H.W. The multifaceted nature of exploration and exploitation: Value of supply, demand, and spatial search for innovation. Organ. Sci. 2007, 18, 20-38. [CrossRef]

77. Alexandrova, M. Entrepreneurship in transition economy: The impact of environment on entrepreneurial orientation. Probl. Perspect. Manag. 2004, 2, 140-148.

78. Lubatkin, M.H.; Simsek, Z.; Ling, Y.; Veiga, J.F. Ambidexterity and performance in small-to medium-sized firms: The pivotal role of top management team behavioral integration. J. Manag. 2006, 32, 646-672. [CrossRef]

79. Sorensen, J.; Stuart, T. Aging, Obsolescence, and Organizational Innovation. Adm. Sci. Q. 2000, 45, 81-112. [CrossRef]

80. Turulja, L.; Bajgoric, N. Innovation, firms' performance and environmental turbulence: Is there a moderator or mediator? Eur. J. Innov. Manag. 2019, 22, 213-232. [CrossRef]

81. Le, H. Foreign Parent Firm Contributions, Experiences, and International Joint Venture Control and Performance. Int. J. Manag. Rev. 2009, 5, 55-69.

82. IBM Corporation. IBM SPSS Advanced Statistics 24; IBM Corporation: Armonk, NY, USA, 2016.

83. Hayes, A.F. Introduction to Mediation, Moderation, and Conditional Process Analysis: A Regression-Based Approach, 2nd ed.; Guilford Press: New York, NY, USA, 2017.

84. Preacher, K.J.; Rucker, D.D.; Hayes, A.F. Addressing moderated mediation hypotheses: Theory, methods, and prescriptions. Multivar. Behav. Res. 2007, 42, 185-227. [CrossRef] [PubMed]

85. Gelman, A. Scaling regression inputs by dividing by two standard deviations. Statist. Med. 2008, 27, 2865-2873. [CrossRef] [PubMed]

86. Anderson, J.C.; Gerbing, D.W. Structural equation modeling in practice: A review and recommended two step approach. Psychol. Bull. 1988, 103, 411-423. [CrossRef]

87. Bagozzi, R.P.; Yi, Y. On the evaluation of structural equation models. J. Acad. Mark. Sci. 1988, 16, 74-94. [CrossRef]

88. Muller, D.; Judd, C.M.; Yzerbyt, V.Y. When moderation is mediated and mediation is moderated. J. Pers. Soc. Psychol. 2005, 89, 852-863. [CrossRef] 
89. James, L.R.; Brett, J.M. Mediators, moderators, and tests for mediation. J. Appl. Psychol. 1984, 69, 307-321. [CrossRef]

90. Bauer, D.J.; Curran, P.J. Probing interactions in fixed and multilevel regression: Inferential and graphical techniques. Multivar. Behav. Res. 2005, 40, 373-400. [CrossRef]

91. Caloghirou, Y.; Kastelli, I.; Tsakanikas, A. Internal capabilities and external knowledge sources: Complements or substitutes for innovative performance? Technovation 2004, 24, 29-39. [CrossRef]

92. Cassiman, B.; Veugelers, R. In search of complementarity in innovation strategy: Internal R and D and external knowledge acquisition. Manag. Sci. 2006, 52, 68-82. [CrossRef]

93. Davide, C.; Vittorio, C.; Federico, F. The Open Innovation Journey: How Firms Dynamically Implement the Emerging Innovation Management Paradigm. Technovation 2011, 31, 34-43.

94. Davide, C.; Vittorio, C.; Federico, F. Unravelling the Process from Closed to Open Innovation: Evidence from Mature, AssetIntensive Industries. $R$ D Manag. 2010, 40, 222-245.

95. Kim, C.Y.; Lim, M.S.; Yoo, J.W. Ambidexterity in External Knowledge Search Strategies and Innovation Performance: Mediating Role of Balanced Innovation and Moderating Role of Absorptive Capacity. Sustainability 2019, 11, 5111. [CrossRef] 